\title{
Comparative study of FDI in Central and Eastern Europe and the Mediterranean
}

\author{
Carlo Altomonte $^{\mathrm{a}, *}$, Claudia Guagliano ${ }^{\mathrm{b}}$ \\ a ISLA-Bocconi University, Milan and KU Leuven, Italy \\ b ISLA-Bocconi University, Milan, Italy
}

\begin{abstract}
The European Union (EU) is currently being exposed to strong integration dynamics. However, the full implications of such dynamics for the location of foreign direct investment (FDI) for both the European Union and the bordering countries are not understood. We construct a panel of more than 3500 European multinationals that have invested in Central and Eastern Europe (CEE) and the Mediterranean (MED) over the 1990-1997 period in 48 NACE 3 industries. After controlling for industry and time-specific effects, it is found that Central and Eastern Europe displays a greater potential in the attraction of FDI flows when compared to the Mediterranean region.
\end{abstract}

(C) 2003 Elsevier B.V. All rights reserved.

JEL classification: $\mathrm{C} 23 ; \mathrm{F} 21 ; \mathrm{P} 20$

Keywords: Panel data; FDI; Transition economies

\section{Introduction}

The integration process of the European Union (EU) has been characterised in the last decade by a two-fold dimension: an internal one, devoted to the creation of a truly single market operating with a single currency, the euro, and a renewed attention to the external dimension of such an integration process, at least as far as its neighbouring borders are concerned.

Specific agreements (Europe agreements) have been signed by 10 Central and Eastern European countries (CEECs) in the early nineties, and were followed between 1998 and 1999 by the official opening of negotiations for the actual accession of these countries to the EU. A historic partnership has also been developed since 1995 with all the South Mediterranean

\footnotetext{
* Corresponding author. ISLA, Università Luigi Bocconi, Via Gobbi, 5, I-20136 Milan. Tel.: +39-02-5836-5405; fax: +39-02-5836-5439.

E-mail address: carlo.altomonte@uni-bocconi.it (C. Altomonte).
} 
(MED) countries (the so-called Barcelona process), leading to the creation of a free trade area by $2010 .{ }^{1}$ And yet, the success of these political operations is linked to the ability of economic agents to support integration with appropriate levels of productive investments.

The emphasis put on the ability of these countries to attract foreign direct investment (FDI), especially from European multinational enterprises (MNEs), in all the European Commission programmes, is not surprising. The importance of structural reforms leading to a stable and working market economy, the implementation of an appropriate and transparent legal framework for the business environment, the restructuring of the industrial base through privatisation programmes are all issues stressed by the European political counterparts, since these factors are all likely to lead to an increased volume of foreign investments in the CEE and MED region, and hence to their rapid integration.

The object of this paper is therefore to provide an assessment of the FDI determinants in these two regions since the start of their integration processes. Section 2 of the paper tries to understand, combining macroeconomic evidence with an analysis of firm-level data on MNEs, whether the two areas have been able to attract multinational corporations since the start of their integration processes, or whether one area crowded out the other instead. Sections 3 and 4 explore the determinants of these FDI dynamics. Section 5 concludes.

\section{Overview of FDI inflows to Central and Eastern Europe and Mediterranean countries}

A fairly extensive academic literature ${ }^{2}$ offers empirical evidence on the role and the determinants of foreign investments. FDI can play an important role in the development process. Capitals transferred from the parent firms add to local stock and contribute to increase the host country's production base and productivity through a more efficient use of existing resources. Foreign investments promote the diffusion of new technologies, know-how and managerial and marketing skills through direct linkages or spillovers to domestic firms. ${ }^{3} \mathrm{Fi}-$ nally FDI may also contribute to improve external imbalances due to their greater propensity to export with respect to domestic firms.

Notwithstanding these widely acknowledged benefits, the two regions which are the object of our study, Central and Eastern European countries and Mediterranean countries, have both only recently opened their economies to foreign investments. As a consequence, the last decade has been characterised by an increase of FDI flows in both areas (Table 1), although the regional trends are different. The MED region benefited from the world-wide

\footnotetext{
${ }^{1}$ Of the 10 CEECs, Czech Republic, Estonia, Hungary, Latvia, Lithuania, Poland, Slovenia and Slovakia will join the EU in 2004, together with Malta and Cyprus, belonging to the MED group. Bulgaria and Romania will follow in 2009. Turkey, another MED country, is currently discussing with the EU the start of a similar process. Algeria, Egypt, Israel, Jordan, Lebanon, Morocco, Syria, Tunisia have all signed a special Association Agreement with the Union or are currently negotiating it.

${ }^{2}$ See Dunning $(1992,1998)$ for a general presentation of the theory of multinational enterprises, Caves (1996) for an application to developing countries, and Markusen $(1995,2002)$ for some hints on the relationships between the theory of MNEs and the new international trade theory. Altomonte (2000) provides a survey of the literature on MNEs in the CEECs, while Reiffers (1997) and Resmini (2002) do the same for the MED region.

3 This effect is, however, controversial in the literature, e.g. Aitken and Harrison (1999).
} 
Table 1

FDI inflows into the CEECs and the MED countries, 1991-2001 (US\$ million)

\begin{tabular}{|c|c|c|c|c|c|c|c|c|c|c|c|}
\hline & 1991 & 1992 & 1993 & 1994 & 1995 & 1996 & 1997 & 1998 & 1999 & 2000 & 2001 \\
\hline \multicolumn{12}{|l|}{ CEECs } \\
\hline Bulgaria & 60 & 42 & 40 & 105 & 90 & 109 & 505 & 537 & 819 & 1002 & 689 \\
\hline Czech Republic & 523 & 1003 & 654 & 869 & 2562 & 1428 & 1300 & 3718 & 6324 & 4986 & 4916 \\
\hline Estonia & & 82 & 162 & 215 & 202 & 150 & 267 & 581 & 305 & 387 & 538 \\
\hline Hungary & 1459 & 1471 & 2339 & 1146 & 4453 & 2275 & 2173 & 2036 & 1944 & 1643 & 2414 \\
\hline Latvia & & 29 & 44 & 213 & 178 & 382 & 521 & 357 & 348 & 408 & 201 \\
\hline Lithuania & & 10 & 30 & 31 & 73 & 152 & 355 & 926 & 486 & 379 & 446 \\
\hline Poland & 359 & 678 & 1715 & 1875 & 3659 & 4498 & 4908 & 6365 & 7270 & 9342 & 8830 \\
\hline Romania & 40 & 77 & 94 & 341 & 419 & 263 & 1215 & 2031 & 1041 & 1025 & 1137 \\
\hline Slovakia & 81 & 100 & 168 & 245 & 195 & 251 & 220 & 684 & 390 & 2075 & 1475 \\
\hline Slovenia & 65 & 111 & 113 & 128 & 177 & 194 & 375 & 248 & 181 & 176 & 442 \\
\hline Total CEECs & 2587 & 3603 & 5359 & 5167 & 12008 & 9703 & 11839 & 17482 & 19108 & 21422 & 21087 \\
\hline \multicolumn{12}{|l|}{ MED } \\
\hline Algeria & 80 & 30 & 0.01 & 0.01 & 0.01 & 270 & 260 & 501 & 507 & 438 & 1196 \\
\hline Cyprus & 82 & 107 & 83 & 75 & 86 & 54 & 76 & 69 & 121 & 163 & 163 \\
\hline Egypt & 253 & 459 & 493 & 1256 & 598 & 636 & 887 & 1065 & 2919 & 1235 & 510 \\
\hline Israel & 346 & 589 & 605 & 442 & 1349 & 1387 & 1628 & 1760 & 2889 & 4392 & 3044 \\
\hline Jordan & -12 & 41 & -34 & 3 & 13 & 16 & 361 & 310 & 158 & 39 & 169 \\
\hline Lebanon & 2 & 4 & 6 & 7 & 35 & 80 & 150 & 200 & 250 & 298 & 249 \\
\hline Malta & 77 & 40 & 56 & 152 & 132 & 277 & 81 & 267 & 822 & 652 & 314 \\
\hline Morocco & 317 & 503 & 590 & 555 & 437 & 357 & 1079 & 333 & 850 & 201 & 2658 \\
\hline Syria & 62 & 18 & 109 & 251 & 100 & 89 & 80 & 82 & 263 & 270 & 205 \\
\hline Tunisia & 173 & 584 & 656 & 566 & 378 & 351 & 365 & 668 & 368 & 779 & 486 \\
\hline Turkey & 810 & 844 & 636 & 608 & 885 & 722 & 805 & 940 & 783 & 982 & 3266 \\
\hline Total MED & 2190 & 3219 & 3201 & 3915 & 4013 & 4240 & 5772 & 6195 & 9930 & 9449 & 12261 \\
\hline
\end{tabular}

Source: UNCTAD-DTCI.

surge in FDI flows that characterised the period 1990-1998, but to a much lesser extent than the CEECs where, since the beginning of transition, FDI inflows have increased by a factor of 10 .

This difference is also clear when analysing FDI flows as a percentage of developing countries (see Table 2). Foreign investments to the CEE area have significantly gained in importance, with an average of $8.3 \%$ in the last 5 years and a peak of $10.7 \%$ in 1995 , in line with the world-wide growth of FDI operations in that year as a consequence of intense merger and acquisition activity, vast privatisation programs implemented in the economies in transition and a continuously improving regulatory framework (Alessandrini,

Table 2

Share of FDI flows in percentage of total developing countries inflows

\begin{tabular}{llllllllllll}
\hline & 1991 & 1992 & 1993 & 1994 & 1995 & 1996 & 1997 & 1998 & 1999 & 2000 & 2001 \\
\hline CEECs & 5.8 & 6.1 & 6.4 & 4.8 & 10.7 & 6.4 & 6.2 & 9.3 & 8.5 & 9.0 & 10.3 \\
MED & 4.9 & 5.4 & 3.8 & 3.6 & 3.6 & 2.8 & 3.0 & 3.3 & 4.4 & 4.0 & 6.0 \\
\hline
\end{tabular}

Source: UNCTAD-DTCI. 
2000). Conversely, FDI into the Mediterranean area, as a percentage of flows to developing countries, has significantly lost in importance, showing some signs of recovery only in 2001. Political and economic instability and a non-transparent, on average, government attitude towards MNEs were major obstacles to FDI inflows, further hampered by a weak enabling environment for privatisation-related FDI and a lack of effective investment promotion activities (Reiffers, 1997).

As far as the location of FDI is concerned, both regions show the formation of different groups of recipient countries. In the MED area the core group of recipient countries encompasses Egypt, Turkey and Israel, with cumulated flows in each country above US\$ 10 million in the period considered ( $62 \%$ of total cumulated inflows to the MED), immediately followed by Morocco and Tunisia. In the CEECs, the core group is more concentrated, being represented by the former "Visegrad" countries (i.e. Poland, Hungary and the Czech Republic), with cumulated flows of more than US\$ 100 billion (78\% of cumulated inflows).

The increased FDI inflows of the two areas over the last decade are also dependent on the European Union strategy aimed at deepening and intensifying its economic relationships with the neighbouring countries (see Appendix A). The subscription of several agreements represented the basis for a wider integration process involving both the Central and Eastern Europe and Mediterranean areas and paving the way to structural economic reforms in the two regions. The location of FDI had a key role in this process.

Over the period 1994-1998, EU FDI to the CEECs amounted to $€ 28.4$ billion, i.e. around $70 \%$ of the total value of the investments recorded in the area and $7 \%$ of EU outflows during the period (see Table 3). Germany alone contributed for $40 \%$ of the total initial value of European initiatives, with total estimated outflows of $€ 11.7$ billion. France came second, with $10.4 \%$ of the cumulative value, followed by Austria and The Netherlands with $9.8 \%$. The position of the United States is also very important, with a total contribution of $€ 9$ billion, invested mainly in Poland, Hungary and the Czech Republic. These three countries together absorb almost $90 \%$ of the American investments in the region.

The EU is the most important investor also in the MED region, even though the Mediterranean countries do not seem to be on top of the European firms' preferences as a location for production plants. In 1998, in fact, the MED region represented only $2 \%$ of total EU outflows. This share declined since 1994, when the region collected about $11 \%$ of total European FDI outflows. Within the EU, only five countries seem to be steadily involved as investors in the MED region, even though with different paces and patterns: France, Germany, Italy, The Netherlands and the UK.

Table 3

EU FDI to the CEECs and MED countries, 1994-98 ( $€$ million)

\begin{tabular}{lrrrrr}
\hline & 1994 & 1995 & 1996 & 1997 & 1998 \\
\hline CEECs & 2824 & 3705 & 5483 & 6975 & 9416 \\
Percentage of extra EU flows & 11 & 8 & 11 & 7 & 5 \\
MED & 2827 & 2779 & 2943 & 4804 & 4679 \\
Percentage of extra EU flows & 11 & 6 & 6 & 5 & 2 \\
\hline
\end{tabular}

Source: Eurostat, European Union Direct Investment Yearbook, 1999. 
Aggregated data on FDI flows and stocks allow however only a limited analysis of the pace and modalities at which the process of economic integration between the European Union and the CEECs and the MED countries is taking place. A more micro-level approach is deemed necessary for deriving some insights on the FDI determinants in these areas and the role of EU firms with respect to this process. The analysis can be carried out exploiting two firm-specific databases registering almost 4400 FDI operations in the CEECs and 1800 operations in the MED region. ${ }^{4}$

In the Central and Eastern European area (Table 4), the EU accounts for the bulk of FDI, with almost $80 \%$ of total initiatives. In particular, German (26\%), Italian (16\%) and Austrian (12\%) entrepreneurs have been the most active investors.

A different picture appears when looking at the number of FDI initiatives in the MED region. Table 5 shows that the number of European initiatives in the area is much lower, around 50\%, with American initiatives being second with 30\%. The European countries that seem to be mainly involved as investors are France (30\% of EU initiatives), Italy (25\% of EU initiatives) and Germany (15\% of EU initiatives).

The economic literature has also highlighted how FDI decisions can be traced back to industry characteristics such as labour costs or production cost differentials, the exploitation of economies of scale and scope, the availability of a qualified labour force and the opportunities for upgrading production techniques and product quality. ${ }^{5}$ Thus, at the micro-economic level, an analysis of sectors is crucial for a better understanding of the FDI dynamics in the CEECs and in the MED area.

As illustrated in Table 6, the manufacturing sector in the CEECs accounted for $62 \%$ of foreign initiatives, while the wholesale and retail trade sector and the financial sector accounted for, respectively, 10 and $8 \%$ of the total number of initiatives. A minor role has been played by agriculture and mining activities. In the MED area, the main sector of activity is also manufacturing, which accounts for more than $60 \%$ of the total number of operations recorded in the area. Financial intermediation comes second, with $12.2 \%$ of initiatives, followed by tourism, with 5.3\%. A significant presence, given the strategic and financial value of each initiative, is displayed in the MED area by the telecommunications sector, accounting for $11 \%$ of total investments in the area, a share twice as high with respect to the CEECs. Disentangling oil-related activities from the sector classification also reveals a particularly high figure for the MED countries, around 5\% of total initiatives.

Within manufacturing, the production of food, chemicals, motor vehicles, machinery, textiles (NACE 17 and 18) and high-tech (NACE 30-32) attracted the greatest number of investments in the CEECs, with these six sectors accounting for roughly $55 \%$ of the total number recorded. In some of those sectors, especially in food and beverages, the strategy chosen for penetration by Western firms often relied on the acquisition, via the privatisation process, of leading local firms. In the MED countries, the prevalence of the chemical (NACE 24) and food (NACE 15) sectors with 21 and $18 \%$ of total MNEs investments is clear,

\footnotetext{
4 The two databases PECODB and DBMEDA have been developed by Sergio Alessandrini at ISLA-Bocconi, Milan. We recall that, being based on sample observations, statistical data for the multinational initiatives are not fully comparable with official statistics derived from balance of payments data or special surveys of FDI. Hence, only a general comparison can be made among the two data sources.

5 See Resmini (2000) for a discussion of sector-level FDI determinants in transition countries.
} 
Table 4

FDI to the CEECs by home and host countries (percentages of total number of MNEs)

\begin{tabular}{|c|c|c|c|c|c|c|c|c|c|c|c|}
\hline & $\begin{array}{l}\text { Bulgaria } \\
(\%)\end{array}$ & $\begin{array}{l}\text { Czech } \\
\text { Republic (\%) }\end{array}$ & $\begin{array}{l}\text { Estonia } \\
(\%)\end{array}$ & $\begin{array}{l}\text { Hungary } \\
(\%)\end{array}$ & $\begin{array}{l}\text { Latvia } \\
(\%)\end{array}$ & $\begin{array}{l}\text { Lithuania } \\
(\%)\end{array}$ & $\begin{array}{l}\text { Poland } \\
(\%)\end{array}$ & $\begin{array}{l}\text { Romania } \\
(\%)\end{array}$ & $\begin{array}{l}\text { Slovakia } \\
(\%)\end{array}$ & $\begin{array}{l}\text { Slovenia } \\
(\%)\end{array}$ & $\begin{array}{l}\text { Total } \\
(\%)\end{array}$ \\
\hline EU-15 & 77.2 & 78.2 & 78.8 & 81.4 & 74.4 & 69.7 & 75.9 & 81.2 & 79.4 & 88.2 & 78.5 \\
\hline United States & 13.2 & 13.7 & 19.6 & 11.6 & 25.6 & 24.7 & 17.6 & 11.8 & 13.1 & 5.9 & 14.8 \\
\hline South Korea & 2.6 & 0.5 & 0.0 & 1.8 & 0.0 & 1.1 & 1.4 & 2.1 & 2.8 & 1.5 & 1.3 \\
\hline Switzerland & 5.3 & 5.3 & 1.6 & 2.8 & 0.0 & 4.5 & 3.5 & 4.5 & 2.8 & 2.9 & 3.8 \\
\hline Japan & 1.8 & 2.4 & 0.0 & 2.3 & 0.0 & 0.0 & 1.5 & 0.3 & 1.9 & 1.5 & 1.6 \\
\hline \multicolumn{12}{|l|}{ EU of which } \\
\hline Germany & 18.2 & 36.0 & 8.1 & 26.1 & 12.5 & 25.8 & 28.8 & 17.9 & 20.0 & 20.0 & 26.7 \\
\hline Italy & 19.3 & 8.2 & 2.0 & 23.0 & 0.0 & 3.2 & 14.9 & 26.9 & 28.2 & 36.7 & 16.1 \\
\hline Austria & 10.2 & 15.1 & 1.3 & 22.1 & 6.3 & 3.2 & 7.2 & 6.3 & 18.8 & 21.7 & 12.5 \\
\hline France & 10.2 & 12.1 & 1.3 & 9.2 & 0.0 & 4.8 & 11.2 & 13.4 & 10.6 & 6.7 & 10.2 \\
\hline Other EU & 42.0 & 28.5 & 87.2 & 19.5 & 81.3 & 62.9 & 37.9 & 35.4 & 22.4 & 15.0 & 34.4 \\
\hline
\end{tabular}

Source: Authors' calculations based on the PECODB dataset. 
Table 5

FDI to the MED countries by home and host countries (percentages of total number of MNEs)

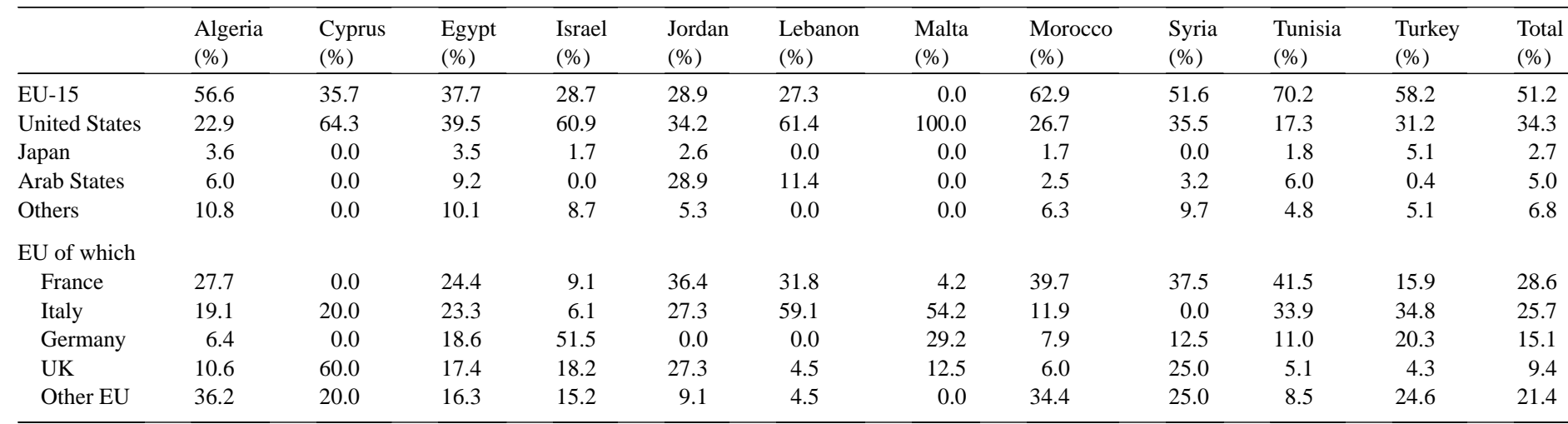

Source: Authors' calculations based on the DBMEDA dataset. 
Table 6

Sectoral breakdown of FDI in the CEEC and MED countries (percentages of total number of MNEs)

\begin{tabular}{lcc}
\hline & CEECs $(\%)$ & MED $(\%)$ \\
\hline Agriculture & 1.0 & 0.2 \\
Mining and quarring & 1.5 & 0.6 \\
Manufacturing & 62.0 & 61.3 \\
Food & 20.4 & 11.9 \\
Textiles & 9.0 & 8.9 \\
Chemical & 8.4 & 22.9 \\
Motor vehicles & 5.8 & 8.5 \\
Machinery & 6.8 & 6.8 \\
High-tech & 9.1 & 14.6 \\
Others & 44.7 & 32.6 \\
Electricity, gas and water supply & 2.9 & 1.2 \\
Construction & 4.0 & 1.2 \\
Wholesale and retail sale & 10.0 & 5.0 \\
Hotels and restaurants & 1.8 & 5.4 \\
Financial intermediation & 8.0 & 12.0 \\
Others & 9.0 & 9.0 \\
\hline
\end{tabular}

Source: Authors' calculations based on the PECODB and DBMEDA datasets.

followed by the high-tech (NACE 30-32), textiles (NACE 17 and 18) and motor vehicles (NACE 34 ) industries, all around $10 \%$ of initiatives.

\section{The econometric analysis}

\subsection{The model}

The proposed econometric model rests on a set of panel data recording the number of investments in each industry $i$ over host country $j$ at time $t$ (cross-sectional, time-series model). The theoretical total number of observations is 6912, covering 48 industries $i$, over 8 years $t$ (1990-1997), in 10 Mediterranean and 8 Central and Eastern European host countries $j .{ }^{6}$ As a result, the panel data set is balanced.

The dependent variable $\mathrm{INV}_{i j t}$ measures the number of investments undertaken by a MNE in industry $i$ at time $t$ for each host country $j$. However, given the relevant number cells where there is no or just one FDI project, the underlying Poisson theoretical distribution of observations is strongly biased. ${ }^{7}$ Since a probit model is a better fit, a binary formulation of the dependent variable is used, in which $\mathrm{INV}_{i j t}$ takes the following values:

$$
\mathrm{INV}_{i j t}= \begin{cases}1 & \text { if an FDI operation is registered in industry } i \text { of country } j \text { in year } t \\ 0 & \text { otherwise. }\end{cases}
$$

\footnotetext{
${ }^{6}$ See Appendix A for a precise classification of countries, industries and data sources.

${ }^{7}$ The fact that in a given industry/country in a given year there are no investments is in any case a significant piece of information.
} 
As a result, a random-effects probit model on the specified panel will be estimated. The estimation technique is based on a generalised maximum-likelihood estimating equation (GEE) approach applied to a generalised linear model (GLM). ${ }^{8}$

The independent variables of the model derive from the traditional literature on FDI location determinants in developing countries (e.g. Caves, 1996), with appropriate modifications in order to take into account the peculiar experience of transition economies. In particular, we include in the estimation three general FDI determinants: demand-related variables, with the aim of controlling for market-seeking strategies of MNEs; comparative advantages, in order to take into account efficiency-seeking strategies; ${ }^{9}$ and institutional variables, since we are dealing with countries which, to a different extent, are experiencing a transition process towards a market economy.

The volume of the local demand for a country $j$ can be proxied by the size of the population $\left(\operatorname{pop}_{j t}\right.$ ) or by different GDP-related measures. Following some of the intuitions developed in the most recent theories of international location (e.g. Head and Mayer, 2001), we include a measure of countries' market access $\left(\right.$ mktacc $\left._{j t}\right)$ as a proxy for local demand, discounting GDP of a country $j$ by its average distance from the "core" European regions (Frankfurt). The intuition behind this variable is that the further a country is localised from a centre of economic activity, the lower will be the pecuniary externalities market-seeking MNEs can possibly exploit in the host country, and hence the larger its local demand to become an attractive location for FDI has to be.

Lacking comparable data on labour costs for the two areas, we control for efficiencyseeking strategies of multinationals through the level of education of the population in each country ( educ $_{j t}$ ), measured as the tertiary gross enrolment ratio (see Appendix A). The sign of the variable is a priori undetermined, since an average higher education of the work force in a country might imply a higher wage structure, as well as higher labour productivity, a measure unfortunately not available for the considered set of countries.

Specifically for countries in transition, a whole literature has developed on the relationships between the quality of business environment/legal framework and the attractiveness of a country for MNEs. ${ }^{10}$ We control in the estimation for these effects in two alternative ways: first, we employ a subjective index of the perceptions of the business environment, $\mathrm{ORI}_{j t}$, computed by a consultancy agency (BERI S.A.) through a panel of experts. Second, we assess the completeness of the local legal framework through an appropriate index, $\mathrm{LAW}_{j t}$, developed by the World Bank.

Given the likely different nature of FDI in such a set of potential locations and time span, in order to minimise the potential bias deriving from unobservable, heterogeneous fixed-effects, a full set of time- and industry-specific dummy variables has been introduced in every estimation. In this way, the error component should only contain country-specific fixed-effects appearing in the constant term.

\footnotetext{
8 The GEE approach used follows in particular Liang and Zeger (1986). We employ a random-effects model, in which the likelihood is expressed as an integral computed using Gauss-Hermite quadrature, rather than a population-averaged model. The latter, although allowing for semi-robust standard errors, implies the (unlikely) assumption of an exchangeable correlation structure on the within-groups correlation matrix, that is, a constant correlation of observations within different groups (i.e. industries in the case considered).

9 This distinction is due to Dunning (1992).

${ }^{10}$ See Altomonte (2000) for a survey and some results applied to the case of CEE countries.
} 
Finally, a structural dummy MED is included to control in the pooled estimating equations for structural heterogeneity deriving from the two different areas considered.

\subsection{The results}

Given the aim of the paper, it is important to disentangle, in the estimations, area and industry-specific effects. To this purpose, three sets of results are presented: estimations for the pooled sample of 48 industries; estimations related to the manufacturing and services industry separately; estimations distinguishing between economies of scale versus traditional industries, according to the Pavitt classification of manufacturing industries (Pavitt, 1984) reported in the Appendix A. To assess the different area-specific effects, in all tables column 1 refers to the pooled CEE and MED sample, column 2 performs the analysis only on CEE countries, while column 3 repeats the exercise for the MED area.

As a robustness check, Tables 7-9 report the results of the econometric analysis relative to the use of the ORI subjective index of business environment, while Tables 10-12 report the same results using the institutional World Bank index (LEG); in addition, all models under column A refer to the analysis employing the market access proxy for local demand, while columns B perform the same exercise using the traditional proxy of local population.

A general comparison of these different specifications does not reveal striking differences in terms of the overall sign and significance of the reported coefficients, thus allowing us to consider the results as relatively robust. Also, the set of industry and time-specific dummy variables, introduced in all equations to control for unobserved heterogeneity, is always found significant at the $1 \%$ level, as indicated by the reported Wald tests on the joint coefficients.

For every sub-sector specification, the local demand affects significantly (at the $1 \%$ level) and positively the probability of undertaking an investment in a given region/industry. The coefficients reported using the market access proxy are slightly lower than the ones obtained using the population variable, reflecting the impact of distance on the market opportunities available in the different locations. However, the pattern of the demand coefficients for both proxies yields an univocal result over the different sector/country specifications: the MED area reports, in all model specifications, a coefficient around 50\% lower than the CEE one (with the difference even being slightly bigger when using the population rather than the market access indicator). Market-seeking strategies seem to prevail in the CEE rather than in the MED area.

The education of the labour force is significant with a negative sign in all estimations relative to the pooled sample of countries and industries (columns $1 \mathrm{~A}$ and $1 \mathrm{~B}$ of Tables 7 and 10). It does not seem to be, instead, a significant FDI determinant when only the services sector are considered, at least in the pooled country estimation (column 1A and 1B of Tables 8 and 11, Services), since in the latter only local demand conditions are likely to be relevant, as is the case for the European Union (Hallet, 2000). With respect to this variable, however, we find a difference when decomposing the analysis between the two areas: in the CEECs education enters with a significant and negative sign in every sector specification; in the MED countries, the education of the work force is significant with a negative sign only in the case of traditional industries (columns 3A and 3B of Tables 9 and 12, Traditional industries), while it is a positive and significant determinant for FDI in the services sector 
Table 7

Pooled sectors and ORI index

\begin{tabular}{|c|c|c|c|c|c|c|}
\hline Variable & 1A Pool & 1B Pool & 2A CEE & 2B CEE & 3A MED & 3B MED \\
\hline mktacc & $0.016^{* * *}(0.001)$ & - & $0.020^{* * *}(0.001)$ & - & $0.012^{* * *}(0.001)$ & - \\
\hline Population & - & $0.019^{* * *}(0.001)$ & - & $0.035^{* * *}(0.002)$ & - & $0.014^{* * *}(0.002)$ \\
\hline Education & $-0.019^{* * *}(0.003)$ & $-0.019^{* * *}(0.003)$ & $-0.035^{* * *}(0.004)$ & $-0.035^{* * *}(0.004)$ & $-0.001(0.005)$ & $0.007(0.005)$ \\
\hline ORI & $0.010^{* *}(0.004)$ & $0.035^{* * *}(0.004)$ & $-0.001(0.006)$ & $0.055^{* * *}(0.007)$ & $0.019^{* * *}(0.007)$ & $0.027^{* * *}(0.007)$ \\
\hline Industry & $9900.22^{* * *}$ & $10226.85^{* * *}$ & $6645.29^{* * *}$ & $7088.77^{* * *}$ & $4138.62^{* * *}$ & $3901.89^{* * *}$ \\
\hline Time & $145.01^{* * *}$ & $164.19^{* * *}$ & $192.32^{* * *}$ & $227.67^{* * *}$ & $14.40^{* *}$ & $11.86^{*}$ \\
\hline MED & $-1.43^{* * *}(0.060)$ & $-1.86^{* * *}(0.071)$ & - & - & - & - \\
\hline No. of observation & 5606 & 5606 & 2735 & 2735 & 2871 & 2871 \\
\hline Wald chi2 & $23166.25^{* * *}$ & $24533.92^{* * *}$ & $10609.93^{* * *}$ & $10934.50^{* * *}$ & $5037.86^{* * *}$ & $4838.81^{* * *}$ \\
\hline
\end{tabular}

Note: Probit random-effects panel data estimations. Standard errors in parentheses. The Wald test of joint significance of the coefficients (Ho: joint coefficients $=0$ ) is reported for the industry and time dummies.

* Significant at the $10 \%$ level.

** Significant at the 5\% level.

*** Significant at the $1 \%$ level. 
Table 8

Manufacturing vs. Services industries and ORI index

\begin{tabular}{|c|c|c|c|c|c|c|}
\hline Variable & 1A Pool & 1B Pool & 2A CEE & 2B CEE & 3A MED & 3B MED \\
\hline \multicolumn{7}{|l|}{ Manufacturing } \\
\hline mktacc & $0.017^{* * *}(0.001)$ & - & $0.021^{* * *}(0.001)$ & - & $0.012^{* * *}(0.002)$ & - \\
\hline Population & - & $0.020^{* * *}(0.001)$ & - & $0.036^{* * *}(0.003)$ & - & $0.015^{* * *}(0.002)$ \\
\hline Education & $-0.023^{* * *}(0.003)$ & $-0.024^{* * *}(0.004)$ & $-0.037^{* * *}(0.005)$ & $-0.036^{* * *}(0.005)$ & $-0.007(0.006)$ & $0.002(0.006)$ \\
\hline ORI & $0.010^{* *}(0.005)$ & $0.036^{* * *}(0.005)$ & $0.002(0.001)$ & $0.062^{* * *}(0.008)$ & $0.018^{* *}(0.008)$ & $0.025^{* * *}(0.008)$ \\
\hline Industry & $7909.12^{* * *}$ & $8243.25^{* * *}$ & $4879.66^{* * *}$ & $5199.63^{* * *}$ & $3449.41^{* * *}$ & $3195.37^{* * *}$ \\
\hline Time & $125.06^{* * *}$ & $141.81^{* * *}$ & $169.34^{* * *}$ & $199.03^{* * *}$ & $12.61^{* *}$ & $10.7^{*}$ \\
\hline MED & $-1.45^{* * *}(0.067)$ & $-1.91^{* * *}(0.080)$ & - & - & - & - \\
\hline Const & $-0.762^{* * *}(0.228)$ & $-1.62^{* * *}(0.254)$ & $-1.01^{* * *}(0.339)$ & $-3.43^{* * *}(0.405)$ & $-1.77^{* * *}(0.361)$ & $-2.34^{* * *}(0.384)$ \\
\hline No. of observation & 4671 & 4671 & 2280 & 2280 & 2391 & 2391 \\
\hline Wald chi2 & $18266.38^{* * * *}$ & $19985.81^{* * *}$ & $7716.19^{* * *}$ & $7968.13^{* * *}$ & $4278.20^{* * *}$ & $4048.1^{* * *}$ \\
\hline \multicolumn{7}{|l|}{ Services } \\
\hline mktacc & $0.013^{* * *}(0.002)$ & - & $0.017^{* * *}(0.003)$ & - & $0.009^{* *}(0.005)$ & - \\
\hline Population & - & $0.014^{* * *}(0.003)$ & - & $0.028^{* * *}(0.007)$ & - & $0.009 *(0.005)$ \\
\hline Education & $-0.003(0.007)$ & $-0.002(0.007)$ & $-0.032^{* * *}(0.011)$ & $-0.032^{* * *}(0.011)$ & $0.019(0.012)$ & $0.026^{* *}(0.013)$ \\
\hline ORI & $0.010(0.011)$ & $0.029^{* * *}(0.011)$ & $-0.022(0.017)$ & $0.023(0.018)$ & $0.027(0.018)$ & $0.033^{*}(0.018)$ \\
\hline Industry & $1382.47^{* * *}$ & $1400.79^{* * *}$ & $1033.66^{* * *}$ & $1079.11^{* * *}$ & $262.43^{* * *}$ & $269.49^{* * *}$ \\
\hline Time & $27.08^{* * *}$ & $29.43^{* * *}$ & $32.86^{* * *}$ & $37.89^{* * *}$ & 5.57 & 5.02 \\
\hline MED & $-1.45^{* * *}(0.142)$ & $-1.75^{* * *}(0.159)$ & - & - & - & - \\
\hline Constant & $-1.85^{* * *}(0.493)$ & $-2.53^{* * *}(0.543)$ & $0.177(0.758)$ & $-1.68^{*}(0.907)$ & $-8.06(16.07)$ & $-7.77^{*}(3.97)$ \\
\hline No. of observation & 935 & 935 & 455 & 455 & 480 & 480 \\
\hline Wald chi2 & $2201.57^{* * *}$ & $2220.47^{* * *}$ & $1428.52^{* * *}$ & $1457.34^{* * *}$ & $275.71^{* * *}$ & $283.74^{* * *}$ \\
\hline
\end{tabular}

Note: Probit random-effects panel data estimations. Standard errors in parentheses. The Wald test of joint significance of the coefficients (Ho: joint coefficients $=0$ ) is reported for the industry and time dummies.

* Significant at the $10 \%$ level.

** Significant at the 5\% level.

*** Significant at the $1 \%$ level. 
Table 9

Economy of scale vs. traditional industries and ORI index

\begin{tabular}{|c|c|c|c|c|c|c|}
\hline Variable & 1A Pool & 1B Pool & 2A CEE & 2B CEE & 3A MED & 3B MED \\
\hline \multicolumn{7}{|c|}{ Economy of scale industries } \\
\hline mktacc & $0.019^{* * *}(0.001)$ & - & $0.023^{* * *}(0.002)$ & - & $0.014^{* * *}(0.003)$ & - \\
\hline Population & - & $0.022^{* * *}(0.002)$ & - & $0.040^{* * *}(0.005)$ & - & $0.019^{* * *}(0.003)$ \\
\hline Education & $-0.026^{* * *}(0.006)$ & $-0.026^{* * *}(0.006)$ & $-0.046^{* * *}(0.008)$ & $-0.045^{* * *}(0.008)$ & $0.001(0.009)$ & $0.014(0.010)$ \\
\hline ORI & $0.019^{* *}(0.008)$ & $0.047^{* * *}(0.008)$ & $0.024^{* *}(0.012)$ & $0.090^{* * *}(0.013)$ & $0.012(0.012)$ & $0.019(0.012)$ \\
\hline Industry & $2790.27^{* * *}$ & $788.46^{* * *}$ & $1426.52^{* * *}$ & $1504.17^{* * *}$ & $930.74^{* * *}$ & $851.48^{* * *}$ \\
\hline Time & $59.63^{* * *}$ & $65.08^{* * *}$ & $86.24^{* * *}$ & $99.13^{* * *}$ & 8.78 & 7.96 \\
\hline MED & $-1.49^{* * *}(0.105)$ & $-1.98^{* * *}(0.126)$ & - & - & - & - \\
\hline Const & $-1.80^{* * *}(0.357)$ & $-2.74^{* * *}(0.407)$ & $-1.64^{* * *}(0.538)$ & $-4.35^{* * *}(0.649)$ & $-3.63^{* * *}(0.554)$ & $-4.34^{* * *}(0.602)$ \\
\hline No. of observation & 1872 & 1872 & 912 & 912 & 960 & 960 \\
\hline Wald chi2 & $4819.08^{* * *}$ & $806.91^{* * *}$ & $1854.79^{* * *}$ & $1924.67^{* * *}$ & $1036.04^{* * *}$ & $972.72^{* * *}$ \\
\hline \multicolumn{7}{|l|}{ Traditional industries } \\
\hline mktacc & $0.017^{* * *}(0.001)$ & - & $0.022^{* * *}(0.002)$ & - & $0.011^{* * *}(0.003)$ & - \\
\hline Population & - & $0.021^{* * *}(0.002)$ & - & $0.036^{* * *}(0.004)$ & - & $0.014^{* * *}(0.003)$ \\
\hline Education & $-0.023^{* * *}(0.006)$ & $-0.024^{* * *}(0.006)$ & $-0.029^{* * *}(0.008)$ & $-0.029^{* * *}(0.008)$ & $-0.024^{* *}(0.010)$ & $-0.016(0.011)$ \\
\hline ORI & $-0.001(0.007)$ & $0.024^{* * *}(0.008)$ & $-0.028^{* *}(0.012)$ & $0.031^{* *}(0.013)$ & $0.032^{* *}(0.013)$ & $0.040^{* * *}(0.014)$ \\
\hline Industry & $3080.06^{* * *}$ & $3192.76^{* * *}$ & $1681.01^{* * *}$ & $1838.77^{* * *}$ & $1268.19^{* * *}$ & $1182.83^{* * *}$ \\
\hline Time & $61.89^{* * *}$ & $69.72^{* * *}$ & $84.79^{* * *}$ & $96.69^{* * *}$ & 7.25 & 6.93 \\
\hline MED & $-1.44^{* * *}(0.105)$ & $-1.91^{* * *}(0.125)$ & - & - & - & - \\
\hline Constant & $-0.301(0.352)$ & $-1.13^{* * *}(0.392)$ & $-0.045(0.531)$ & $-2.44^{* * *}(0.635)$ & $-1.98^{* * *}(0.610)$ & $-2.52^{* * *}(0.653)$ \\
\hline No. of observation & 1863 & 1863 & 912 & 912 & 951 & 951 \\
\hline Wald chi2 & $6956.57^{* * *}$ & $7186.06^{* * *}$ & $2419.27^{* * *}$ & $2555.07^{* * *}$ & $1756.34^{* * *}$ & $1697.33^{* * *}$ \\
\hline
\end{tabular}

Note: Probit random-effects panel data estimations. Standard errors in parentheses. The Wald test of joint significance of the coefficients (Ho: joint coefficients $=0$ ) is reported for the industry and time dummies.

** Significant at the $5 \%$ level.

*** Significant at the $1 \%$ level. 
Table 10

Pooled sectors and LAW index

\begin{tabular}{|c|c|c|c|c|c|c|}
\hline Variable & 1A Pool & 1B Pool & 2A CEE & 2B CEE & 3A MED & 3B MED \\
\hline mktacc & $0.016^{* * *}(0.001)$ & - & $0.020^{* * *}(0.001)$ & - & $0.013^{* * *}(0.001)$ & - \\
\hline Population & - & $0.017^{* * *}(0.001)$ & - & $0.032^{* * *}(0.003)$ & - & $0.016^{* * *}(0.002)$ \\
\hline Education & $-0.015^{* * *}(0.003)$ & $-0.013^{* * *}(0.003)$ & $-0.038^{* * *}(0.006)$ & $-0.046^{* * *}(0.006)$ & $0.001(0.005)$ & $0.012^{* *}(0.005)$ \\
\hline LAW & $0.147^{* * *}(0.032)$ & $0.253^{* * *}(0.033)$ & $0.200^{* * *}(0.050)$ & $0.465^{* * *}(0.052)$ & $0.109 *(0.057)$ & $0.174^{* * *}(0.059)$ \\
\hline Industry & $7223.49^{* * *}$ & $7572.46^{* * *}$ & $5051.54^{* * *}$ & $5608.78^{* * *}$ & $4153.90^{* * *}$ & $3866.12^{* * *}$ \\
\hline Time & $42.45^{* * *}$ & $31.20^{* * *}$ & $74.65^{* * *}$ & $50.68^{* * *}$ & $11.69^{*}$ & $11.22^{*}$ \\
\hline MED & $-1.23^{* * *}(0.073)$ & $-1.36^{* * *}(0.074)$ & - & - & - & - \\
\hline Constant & $-0.823^{* * *}(0.172)$ & $-1.13^{* * *}(0.186)$ & $-1.47^{* * *}(0.258)$ & $-2.50^{* * *}(0.287)$ & $-1.46^{* * *}(0.192)$ & $-1.89^{* * *}(0.219)$ \\
\hline No. of observation & 4742 & 4742 & 1871 & 1871 & 2871 & 2871 \\
\hline Wald chi2 & $15954.01^{* * *}$ & $16589.38^{* * *}$ & $7217.43^{* * *}$ & $7614.63^{* * *}$ & $4959.80^{* * *}$ & $4699.26^{* * *}$ \\
\hline
\end{tabular}

Note: Probit random-effects panel data estimations. Standard errors in parentheses. The Wald test of joint significance of the coefficients (Ho: joint coefficients $=0)$ is reported for the industry and time dummies.

* Significant at the $10 \%$ level.

** Significant at the 5\% level.

*** Significant at the $1 \%$ level. 
Table 11

Manufacturing vs. services industries and LAW index

\begin{tabular}{|c|c|c|c|c|c|c|}
\hline Variable & 1A Pool & 1B Pool & 2A CEE & 2B CEE & 3A MED & 3B MED \\
\hline \multicolumn{7}{|l|}{ Manufacturing } \\
\hline mktacc & $0.017^{* * *}(0.001)$ & - & $0.021^{* * *}(0.001)$ & - & $0.013^{* * *}(0.002)$ & - \\
\hline Population & - & $0.018^{* * *}(0.001)$ & - & $0.031^{* * *}(0.003)$ & - & $0.016^{* * *}(0.002)$ \\
\hline Education & $-0.019^{* * *}(0.004)$ & $-0.017^{* * *}(0.004)$ & $-0.038^{* * *}(0.006)$ & $-0.045^{* * *}(0.006)$ & $-0.003(0.006)$ & $0.007(0.006)$ \\
\hline LAW & $0.143^{* * *}(0.036)$ & $0.255^{* * *}(0.037)$ & $0.208^{* * *}(0.054)$ & $0.476^{* * *}(0.056)$ & $0.071(0.063)$ & $0.138^{* *}(0.065)$ \\
\hline Industry & $5824.83^{* * *}$ & $6123.06^{* * *}$ & $3954.21^{* * *}$ & $4407.48^{* * *}$ & $3497.54^{* * *}$ & $3214.67^{* * *}$ \\
\hline Time & $34.20^{* * *}$ & $23.95^{* * *}$ & $63.21^{* * *}$ & $39.71^{* * *}$ & 10.14 & 9.29 \\
\hline MED & $-1.24^{* * *}(0.081)$ & $-1.39^{* * *}(0.083)$ & - & - & - & - \\
\hline Const & $-0.703(0.189)$ & $-1.03^{* * *}(0.204)$ & $-1.47^{* * *}(0.280)$ & $-2.49^{* * *}(0.312)$ & $-1.22^{* * *}(0.211)$ & $-1.67^{* * *}(0.240)$ \\
\hline No. of observation & 3951 & 3951 & 1560 & 1560 & 2391 & 2391 \\
\hline Wald chi2 & $12810.25^{* * *}$ & $13554.26^{* * *}$ & $5364.50^{* * *}$ & $5677.09^{* * *}$ & $4212.88^{* * *}$ & $3941.57^{* * *}$ \\
\hline \multicolumn{7}{|l|}{ Services } \\
\hline mktacc & $0.013^{* * *}(0.002)$ & - & $0.018^{* * *}(0.004)$ & - & $0.011^{* *}(0.004)$ & - \\
\hline Population & - & $0.013^{* * *}(0.003)$ & - & $0.033^{* * *}(0.008)$ & - & $0.013^{* *}(0.005)$ \\
\hline Education & $-0.001(0.008)$ & $0.002(0.008)$ & $-0.040^{* * *}(0.015)$ & $-0.049^{* * *}(0.015)$ & $0.021^{*}(0.011)$ & $0.031^{* *}(0.012)$ \\
\hline LAW & $0.176^{* *}(0.080)$ & $0.256^{* * *}(0.082)$ & $0.152(0.128)$ & $0.407^{* * *}(0.133)$ & $0.269 *(0.149)$ & $0.321^{* *}(0.153)$ \\
\hline Industry & $980.73^{* * *}$ & $1020.92^{* * *}$ & $700.1^{* * *}$ & $727.02^{* * *}$ & $256.29^{* * *}$ & $270.20^{* * *}$ \\
\hline Time & $14.58^{* *}$ & $13.29^{* *}$ & $18.78^{* * *}$ & $17.85^{* * *}$ & 6.49 & 6.46 \\
\hline MED & $-1.24^{* * *}(0.174)$ & $-1.33^{* * *}(0.172)$ & - & - & - & - \\
\hline Constant & $-2.11^{* * *}(0.438)$ & $-2.35^{* * *}(0.474)$ & $-1.08^{*}(0.646)$ & $-2.13^{* * *}(0.726)$ & $-6.65^{*}(2.58)$ & $-7.17^{*}(3.95)$ \\
\hline No. of observation & 791 & 791 & 311 & 311 & 480 & 480 \\
\hline Wald chi2 & $1460.67^{* * *}$ & $1507.14^{* * *}$ & $945.38^{* * *}$ & $969.89^{* * *}$ & $271.25^{* * *}$ & $288.51^{* * *}$ \\
\hline
\end{tabular}

Note: Probit random-effects panel data estimations. Standard errors in parentheses. The Wald test of joint significance of the coefficients (Ho: joint coefficients $=0$ ) is reported for the industry and time dummies.

* Significant at the $10 \%$ level.

** Significant at the 5\% level.

*** Significant at the $1 \%$ level. 
Table 12

Economy of scale vs. traditional industries and LAW index

\begin{tabular}{|c|c|c|c|c|c|c|}
\hline Variable & 1A Pool & 1B Pool & 2A CEE & 2B CEE & 3A MED & 3B MED \\
\hline \multicolumn{7}{|c|}{ Economy of scale industries } \\
\hline mktacc & $0.018^{* * *}(0.001)$ & - & $0.023^{* * *}(0.002)$ & - & $0.015^{* * *}(0.003)$ & - \\
\hline Population & - & $0.019^{* * *}(0.002)$ & - & $0.033^{* * *}(0.005)$ & - & $0.020^{* * *}(0.003)$ \\
\hline Education & $-0.019^{* * *}(0.006)$ & $-0.017^{* *}(0.006)$ & $-0.051^{* * *}(0.011)$ & $-0.058^{* * *}(0.010)$ & $0.003(0.008)$ & $0.018(0.009)$ \\
\hline LAW & $0.158^{* * *}(0.055)$ & $0.278^{* * *}(0.057)$ & $0.317^{* * *}(0.088)$ & $0.609^{* * *}(0.092)$ & $-0.019(0.096)$ & $0.066(0.102)$ \\
\hline Industry & $2030.92^{* * *}$ & $2168.88^{* * *}$ & $1037.05^{* * *}$ & $1147.71^{* * *}$ & $904.00^{* * *}$ & $818.38^{* * *}$ \\
\hline Time & $23.42^{* * *}$ & $18.02^{* * *}$ & $37.64^{* * *}$ & $25.34^{* * *}$ & 8.89 & 7.95 \\
\hline MED & $-1.22^{* * *}(0.125)$ & $-1.37^{* * *}(0.126)$ & - & - & - & - \\
\hline Const & $-1.82^{* * *}(0.297)$ & $-2.14^{* * *}(0.323)$ & $-2.06^{* * *}(0.462)$ & $-3.17^{* * *}(0.517)$ & $-3.13^{* * *}(0.346)$ & $-3.71^{\text {*** }}(0.403)$ \\
\hline No. of observation & 1584 & 1584 & 624 & 624 & 960 & 960 \\
\hline Wald chi2 & $3255.24^{* * *}$ & $3477.89^{* * *}$ & $1219.46^{* * *}$ & $1311.18^{* * *}$ & $992.43^{* * *}$ & $916.40^{* * *}$ \\
\hline \multicolumn{7}{|l|}{ Traditional industries } \\
\hline mktacc & $0.017^{* * *}(0.001)$ & - & $0.023^{* * *}(0.002)$ & - & $0.013^{* * *}(0.003)$ & - \\
\hline Population & - & $0.021^{* * *}(0.002)$ & - & $0.038^{* * *}(0.005)$ & - & $0.016^{* * *}(0.003)$ \\
\hline Education & $-0.022^{* * *}(0.007)$ & $-0.021^{* * *}(0.007)$ & $-0.029^{* * *}(0.010)$ & $-0.038^{* * *}(0.010)$ & $-0.019 *(0.010)$ & $-0.009(0.011)$ \\
\hline LAW & $0.111^{* *}(0.056)$ & $0.233^{* * *}(0.058)$ & $0.072(0.084)$ & $0.378^{* *}(0.087)$ & $0.172 *(0.098)$ & $0.233^{* *}(0.102)$ \\
\hline Industry & $2219.88^{* * *}$ & $2324.24^{* * *}$ & $1373.47^{* * *}$ & $1514.18^{* * *}$ & $1349.04^{* * *}$ & $1265.88^{* * *}$ \\
\hline Time & $19.52^{* * *}$ & $15.38^{* *}$ & $41.31^{* * *}$ & $28.54^{* * *}$ & 6.16 & 7.10 \\
\hline MED & $-1.34^{* * *}(0.131)$ & $-1.52^{* * *}(0.135)$ & - & - & - & - \\
\hline Constant & $-0.454(0.296)$ & $-0.838^{* * *}(0.321)$ & $-1.13(0.426)$ & $-2.36^{* * *}(0.482)$ & $-1.08^{* * *}(0.335)$ & $-1.47^{* * *}(0.380)$ \\
\hline No. of observation & 1575 & 1575 & 624 & 624 & 951 & 951 \\
\hline Wald chi2 & $5247.17^{* * *}$ & $5570.18^{* * *}$ & $1793.89^{* * *}$ & $1910.76^{* * *}$ & $1751.62^{* * *}$ & $1692.88^{* * *}$ \\
\hline
\end{tabular}

Note: Probit random-effects panel data estimations. Standard errors in parentheses. The Wald test of joint significance of the coefficients (Ho: joint coefficients $=0$ ) is reported for the industry and time dummies.

* Significant at the $10 \%$ level.

** Significant at the 5\% level.

*** Significant at the $1 \%$ level. 
(columns 3A and 3B of Tables 8-11, Services), where probably considerations linked to the quality of the human capital tend to emerge. However, in general also the variable dealing with efficiency-seeking strategies related to the exploitation of comparative advantages displays a higher coefficient in the CEE countries with respect to the MED region, even controlling for industry-specific effects.

In terms of business environment and legal framework, the coefficients are in general significant with a positive sign, as expected, in all estimations. There are however some technical considerations to take into account. In particular, the ORI coefficient seems to be affected, especially in the CEE sub-samples, by the alternative specifications of the two indexes proxying local demand, a sign of potential multicollinearity, likely due to the fact that proxying local demand with the population leaves a greater portion of variance unexplained, an unobserved heterogeneity captured by the (subjective) ORI indicator rather than by the legal framework variable. ${ }^{11}$ We can therefore conclude that the LAW indicator is possibly more robust to alternative model specifications, and limit ourselves to its discussion.

The indicator of legal framework is significant in the CEECS with a positive sign in the manufacturing industries and not in services, and among manufacturing in economies of scale industries and not in traditional ones (Tables 11 and 12, column 2A). This is consistent with theoretical priors, reflecting the fact that investment with higher sunk costs (higher proportion of physical capital committed, or larger dimensions) tend to react more to the quality of the local legal environment (Altomonte, 2000; Lankes and Venables, 1996).

On the contrary, no similar clear-cut conclusions can be drawn in the case of MED countries. In this case, although the index is always significant in the pooled sector estimations (Table 10, columns 3A and 3B), such a significance is not robust across the alternative industry-specific models. This might be due to the peculiar legal framework in the CEECs countries which, contrary to the MED, did experience a convergence toward a common set of rules (the so-called acquis communautaire) needed for their accession to the EU. On the contrary, the MED countries tended to maintain their differentiated, and often incomplete, legal frameworks.

Finally, consistently with the evidence previously reported, the striking differences between the CEE and the MED countries in terms of FDI determinants are picked by the strong significance of the MED dummy in every model specification (columns $1 \mathrm{~A}$ and $1 \mathrm{~B}$ ).

\section{Economic integration and FDI location}

When trying to understand what explains the differences in the capacity of FDI attraction between the two areas, we have seen that, even after controlling for industry and time-specific effects, the CEE area structurally displays a greater potential in the attraction of FDI flows with respect to the MED one, in terms of both market and efficiency-seeking MNEs strategies. Nor does the MED region seem to be specifically constrained in its capacity

\footnotetext{
11 Note how the columns B in Tables 7-9, employing ORI, yielded higher and on average more significant coefficients with respect to the models using market access reported in columns A, for all sub-sample specifications; this effect is not present in Tables 10-12, where LAW replaces ORI.
} 
of attracting FDI from factors related to its legal framework, at least judging from the level of significance of this variable.

As a result, the unobserved underlying characteristic responsible for the different performance of the two areas might be related to the presence of stronger pecuniary externalities for MNEs in the CEE countries with respect to the ones currently existing in the MED region: in other words, from what is known as a lower "market potential" of the latter region (in the spirit of Harris, 1954). In fact, while it is likely that MNEs evaluate the local demand measured at the country-level in their investment decisions, they are also likely to consider the demand of neighbouring locations, because as long as there are some relatively free trade opportunities, part of the total demand addressed to MNEs will come from consumers located just outside the boundaries of the host country chosen as their foreign production base (Head and Mayer, 2001). Therefore, the higher segmentation of regional markets in the MED, also in terms of non-tariff barriers (Reiffers, 1997), could be responsible for this lower attraction capacity of the area when competing on equal grounds with the CEECs.

In order to test this assumption, we have calculated an indicator of market access as the sum of the bilateral trade of each country $j$ with the other $s$ partner countries belonging to the same region, discounted by their geographical distance. Formally, denoting $m_{j s}$ as the imports of country $j$ from country $s$ and $d_{j \mathrm{~s}}$ as the distance between the two countries, the degree of integration of country $j$ in the area at time $t$ is measured as $\tau_{j t}=\sum_{s} m_{j s} / d_{j s}$. Figs. 1 and 2 compare this measure of integration, calculated for all the CEECs and MED countries, with the growth of FDI inflows, as measured from our databases. As it can be seen, while at the beginning of the last decade the MED region was experiencing a level of integration even higher than the CEECs, over the years the two figures started to diverge, with the CEECs index increasing by an overall factor of 5 against a mere factor of 0.7 in the MED countries; the two indexes approached a parallel evolution again only in the late 1990s (Fig. 2). Over the same decade, and in parallel with the dynamics of the trade integration indicator, the gap between the CEECs and the MED countries in terms of FDI opened up (Fig. 1).

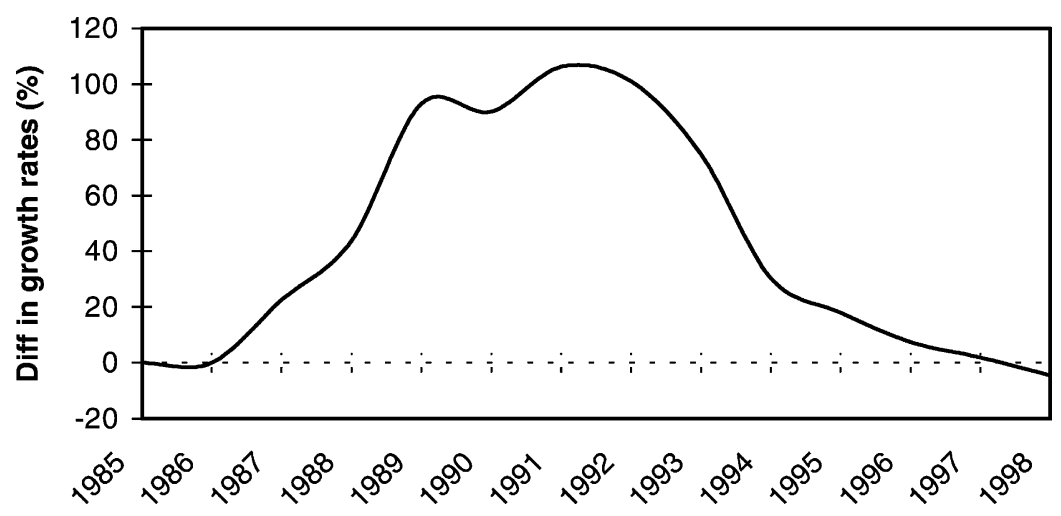

Fig. 1. The growth rates differential of FDI inflows between CEE and MED countries (difference in yearly growth rates of the total number of FDI). Source: Authors' calculations from the PECODB and DBMEDA datasets. 


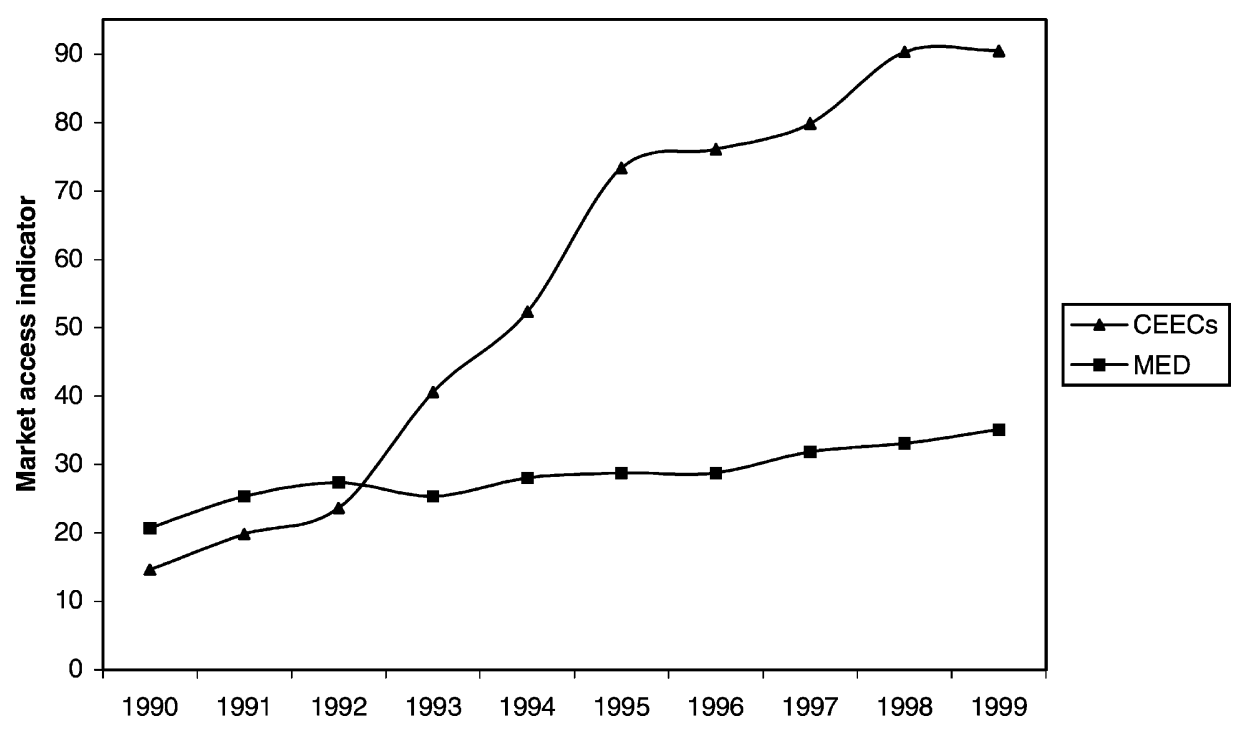

Fig. 2. The evolution of the market access indicator in CEECs and MED countries. Source: Authors' calculations from IMF, Direction of Trade Statistics, various years.

An econometric test can assess the robustness of this finding. To this purpose, lacking industry-specific information on bilateral trade flows, we have constructed a panel dataset using as a dependent variable the (log) FDI inflows of the jth country for each year $t$, as derived from the data at the basis of Table 1 . The total number of countries (18, see Appendix A) and years (from 1991 to 2000) considered in our analysis yield a panel of 180 observations.

Holding a country-specific fixed-effect specification to control for differences in comparative advantages, we can turn our attention to the independent variables recording the market potential of each country in the considered region, measuring it in three different ways as a robustness check. The first measure, denoted as $M_{j t}$, represents the total expenditures of a given country and is simply proxied through the (log) GDP of each country in each year. The second measure of market potential, specifically based on our intuition, interacts each country GDP with the degree of trade integration $\tau_{j t}$ previously considered and taken in logs. Finally, the third measure of market potential, which we denote as $M$ (Harris ${ }_{j t}$, is the traditional definition of market potential reported by Harris (1954), calculated as the sum of each country $j$ 's (log) GDP plus the GDP of the $s$ countries in the region discounted by their respective distances with country $j$.

Given the evidence of possible clusters of FDI in given countries, we specifically control for agglomeration effects through the number of competing firms. This last variable, which we denote comp $p_{j t}$, is obtained through the country-specific yearly cumulated number of MNEs as derived from the two datasets PECODB and DBMEDA and taken in logs.

Clearly, to avoid simultaneity, all data related to the independent variables have been lagged one period. Due to data availability, this reduces our time horizon as measured 
Table 13

FDI and economic integration

\begin{tabular}{llll}
\hline Variable & 1 & 2 & 3 \\
\hline$\tau_{j t}$ & - & $2.50^{* *}(1.05)$ & - \\
$M_{j t}$ & $1.18^{* * *}(0.322)$ & $1.61^{* * *}(0.362)$ & - \\
$M_{j t}^{*} \tau_{j t}$ & $-0.279^{* * *}(0.103)$ & - \\
$M(\text { Harris })_{j t}$ & - & - & $2.01^{* *}(0.844)$ \\
Comp $j t$ & - & $0.779^{* * *}(0.157)$ & $0.443^{* * *}(0.123)$ \\
Country & $0.553^{* * *}(0.125)$ & $2.52^{* *}$ & 1.07 \\
Time & 1.66 & $19.53^{* * *}$ & $14.72^{* * *}$ \\
Constant & $20.67^{* * *}$ & $-11.64^{* * *}(3.67)$ & $-7.85(5.25)$ \\
No. of observation & $-7.23^{* *}(3.25)$ & 129 & 135 \\
$R^{2}$ & 135 & 0.51 & 0.33 \\
$F$-test & 0.49 & $9.36^{* * *}$ & $8.74^{* * *}$ \\
\hline
\end{tabular}

Note: Probit fixed-effects panel data estimations. Standard errors in parentheses. The $F$-test of joint significance of the coefficients (Ho: joint coefficients $=0$ ) is reported for the county and time dummies.

** Significant at the $5 \%$ level.

*** Significant at the $1 \%$ level.

on the dependent variable from 1992 to 1999 included. In addition to country-specific fixed-effects, time-specific effects have been included in the estimations, to control for sources of unobserved heterogeneity other than the trade integration dynamics. Finally, since bilateral trade data of Syria are very poor, this country has been dropped from the econometric estimation.

Table 13 reports the results of the econometric analysis. The first column represents our benchmark model, with the market potential estimated only through $M_{s t}$, the GDP of each country. Our theoretical hypothesis is tested in the second column, where the market potential is measured through the interaction of $M_{j t}$ with our trade integration measure $\tau_{j t}$. In the third column, the market potential measured according to the traditional Harris' definition is reported.

Consistently with our predecessors and the reported evidence, model 2 , the one where our theoretical hypothesis is tested, seems the one to better fit our data, with the trade integration variable having the highest positive impact on the determination of FDI flows. In this model, both country-specific fixed-effects and time effects report significant coefficients. It can be noted how GDP alone (first column) is a good predictor of FDI flows, in line with standard results in the literature, achieving a goodness of fit almost as high as the model corrected for trade integration; however, when the latter correction is taken into account, the coefficient of GDP on FDI flows, always significant, is magnified (1.61 in model 2 versus 1.18 in model 1). The negative and significant coefficient reported by the interaction term in model 2 reveals a structural bias of all the measures of transport costs based on trade-related variables, which tend to overweight small open economies (such as Slovenia, for example). Column 3 displays the result obtained with the traditional measure of market potential as derived by Harris (1954): although the coefficient is fairly high, positive and significant, the overall goodness of fit obtained through the use of this measure is rather poor $(0.33$ against an average of 0.5 in the first two models). 
Finally, it can be noted how the variable measuring agglomeration effects among MNEs is significant with a positive sign, in line with the empirical evidence and the results available in the literature (see in particular Altomonte and Resmini, 2002).

\section{Conclusions and further lines of research}

When trying to understand the explanation of the differences in the location of FDI recorded in the two regions considered in the paper, we have seen that both the empirical evidence and an industry-specific econometric model of FDI determinants consistently point to the fact that the CEECs display a greater capacity in the attraction of FDI flows with respect to the MED countries. Our further econometric analysis reveals that this is likely due to the higher degree of integration achieved among the CEECs: this structural characteristic of the Central and Eastern European region enhances the access to markets MNEs can serve from a location in the CEECs, and hence, contrary to the MED experience, over time generates increasing FDI inflows in the area.

The good news, from an economic policy point of view, is that the start of the Barcelona process in 1995, which has raised the prospects of regional integration also for the MED countries through the projected Euro-MED free trade area, seem to have re-balanced the drain of FDI from this region, yielding virtually no widening differences in the last 2 years between the MED countries and the CEECs in terms of FDI growth (see Fig. 1). However, because of this "lost decade", structural and permanent gaps in terms of share of EU foreign direct investment in the two regions are likely to persist for some time if policy makers do not speed up, especially within the area, the removal of trade and non-trade (in particular regulatory) barriers still hindering cross-countries flows of trade and FDI.

Clearly, these findings need to be refined. First, it is necessary to correct for the bias in favour of small open economies generated by the employed measure of trade integration. Some appropriate manipulations of the market potential index, eventually through the use of gravity-type trade equations, could possibly represent a solution to this problem. Second, a better measure of the agglomeration effects has to be found. Partitioning the dependent variable along sector characteristics through the use of the two firm specific datasets whose potentialities have been only marginally exploited in the latest estimation, could represent a solution, allowing for a higher number of observations, and hence for the use of more sophisticated, sector or firm-specific, measures of competition. Finally, it is necessary to perform a more detailed analysis of the interactions existing between international flows of capital and international trade, when integration dynamics are considered. We leave this to our and other scholars' further lines of research.

\section{Acknowledgements}

The authors wish to thank Sergio Alessandrini, Paul Walsh and two anonymous referees for their comments and suggestions. The possibility of exploiting the databases PECODB and DBMEDA, both developed by Sergio Alessandrini at ISLA-Bocconi, is also gratefully acknowledged. The usual disclaimer applies. 


\section{Appendix A. The dataset}

\section{A.1. Country classification}

\begin{tabular}{ll}
\hline Central and Eastern European & Bulgaria, Czech Republic, Hungary, Estonia, \\
$(\mathrm{CEE})$ countries & Poland, Romania, Slovakia and Slovenia \\
Mediterranean (MED) & Algeria, Cyprus, Egypt, Israel, Jordan, \\
countries & Lebanon, Morocco, Syria, Tunisia, Turkey \\
\hline
\end{tabular}

\section{A.2. Industry classification-NACE Rev. 1, 1993}

(a) 1 Mining industry

$10,11,12,13$ and 14 (mining of coal, metals, stone, extraction of petroleum and natural gas).

(b) 39 Manufacturing industries (Pavitt, 1984: two and three digits classification of sunk costs adapted to NACE Rev. 1).

\section{A.2.1. Economies of scale industries}

21 (paper and pulp); 22 (publishing and press); 241 and 242 (basic chemicals and agro-chemicals); 245 (soaps and detergents); 246 and 247 (other chemical products and synthetic fibres); 251 (rubber products); 26 (other non-metallic products); 27 (metallurgy); 297 (domestic appliances); 31 (electrical appliances, excluding domestic); 321 (electronics); 322 and 323 (communication equipment); 341 (car production); 343 (car components); 351 (ship building); 352 and 354 (railways; motorcycles).

\section{A.2.2. Traditional industries}

151 and 152 (production and transformation of meat and fish); 153 and 155 (vegetables, milk and dairy products); 156 and 157 (grains and pet food); 158 and 159 (fabrication of bread, tea, coffee and other alimentary products including drink and beverages); 16 (tobacco); 17 (textiles); 18 (clothing); 19 (leather); 20 (wood); 28 (metals); 361 and 362 (furniture); 363 and 365 (musical instruments and toys); 366 (other general manufacturing).

\section{A.2.3. Specialised industries}

243 (paintings); 252 (plastic products); 291 (mechanical machinery); 292 (general machinery); 293 (agricultural machines); 294 and 295 (machine tools); 334 and 335 (optics, photography, clocks).

\section{A.2.4. High-tech industries}

244 (pharmaceuticals); 30 (office machines and computers); 331 and 332 (medical and precision instruments).

(c) 8 Services industries

401 and 402 (electricity and gas); 45 (construction); 55 (hotels and restaurants); 642 (telecommunications); 65 and 66 (financial intermediation and insurance); 72 (computer 
and related activities); 73 (research and development); 92 (cultural and sporting activities).

\section{A.3. Data definitions and sources}

FDI

Pop

GDP

Distance

Education

\section{LAW}

ORI

$m_{j s}$
Inflows in US\$ million, Annex Table B.1 in UNCTAD, World Investment Report, various years. Host country population in million, World Bank: World Development Indicators.

Host country GDP (at market prices, in US\$ million), World Bank: World Development Indicators.

The distance in kilometres between the host country capital city and an ideal Central European location, chosen in the city of Frankfurt. The measurement of distance is done through a standard route software. Gross enrolment ratio: the ratio of total enrolment in tertiary education, regardless of age, to the population of the age group that officially corresponds to the level of education shown (in this case, 15-24 years), World Bank: World Development Indicators.

An index 0-10 measuring the completeness of the legal framework with respect to a modern market economy. World Bank.

An index 0-100 elaborated through the yearly country ratings of a permanent panel of 105 experts around the world, with 100 indicating ideal business conditions, BERI S.A. c.i.f. bilateral imports, as retrieved from IMF, Direction of Trade Statistics, various years.

\section{References}

Aitken, B.J., Harrison, E., 1999. Do domestic firms benefit from direct foreign investment? Evidence from Venezuela. Am. Econ. Rev. 89, 605-618.

Alessandrini, S. (Ed.), 2000. The EU Foreign Direct Investment in Central and Eastern Europe. Giuffrè Editore, Milan.

Altomonte, C., 2000. Economic determinants and institutional frameworks: FDI in economies in transition. Transnational Corporations 9, August 2000.

Altomonte, C., Resmini, L., 2002. Multinational corporations as a catalyst for industrial development: the case of Poland. Scienze Regionali 2, 29-58.

Caves, R., 1996. Multinational Firms and Economic Analysis, 2nd ed. Cambridge University Press, Cambridge.

Dunning, J.H., 1992. Multinational Enterprises and the Global Economy. Addison-Wesley, London.

Dunning, J.H., 1998. Location and the multinational enterprise: a neglected factor? J. Int. Business Stud. 29, 45-66.

Hallet, M., 2000. Regional specialisation and concentration in the EU. Economic Paper 141, European Commission, Brussels.

Harris, C., 1954. The market as a factor in the localization of industry in the United States. Ann. Assoc. Am. Geogr. 64, 315-348.

Head, K., Mayer, T., 2001. Market potential and the location of Japanese investment in the European Union. In: Proceedings of the CEPR Workshop on the Economic Geography of Europe: Measurement, Testing and Policy Simulations. Villars, 12-13 January 2001. 
Lankes, H.P., Venables, A.J., 1996. Foreign direct investment in economic transition: the changing pattern of investments. Econ. Trans. 4, 331-347.

Liang, K.-Y., Zeger, S.L., 1986. Longitudinal data analysis using generalised linear models. Biometrika 73, 13-22. Markusen, J.R., 1995. The boundaries of multinational enterprises and the theory of international trade. J. Econ. Perspect. 9, 169-189.

Markusen, J.R., 2002. Multinational Firms and the Theory of International Trade. MIT Press, Cambridge, MA

Pavitt, K., 1984. Sectoral patterns of technical change: towards a taxonomy and a theory. Research Policy 13, 343-373.

Reiffers, J.L., 1997. La Méditerranée aux portes de l'an 2000. Institut de la Méditerranée, Economica, Marseille.

Resmini, L., 2000. The determinants of foreign direct investment in the CEECs: new evidence from sectoral patterns. Econ. Trans. 8, 665-689.

Resmini, L., 2002. Interpreting inward FDI in the Mediterranean Basin and in Central and Eastern Europe: why so different? ISLA-Bocconi University Discussion Paper 4. 